\title{
THE DECLINING PRICE OF PERSONAL COMPUTERS THE QUESTION OF WHEN TO INVEST
}

\author{
by \\ Boaz Ronen \\ Recanati Graduate School of Business \\ Tel Aviv University \\ Tel Aviv, 69978 Israel \\ Henry C. Lucas, Jr. \\ Leonard N. Stern School of Business \\ Information Systems Department \\ New York University \\ 90 Trinity Place \\ New York, NY 10006 \\ and \\ Yoram Eden \\ Recanati Graduate School of Business \\ Tel Aviv University \\ Tel Aviv, 69978 Israel
}

April 1989

Center for Research on Information Systems

Information Systems Department

Leonard N. Stern School of Business

New York University

\section{Working Paper Series}

CRIS \#207

STERN \#89-47 
THE DECLINING PRICE OF PERSONAL COMPUTERS:

THE QUESTION OF WHEN TO INVEST

\section{$\underline{\text { ABSTRACT }}$}

When should a manager invest in new technology? This paper provides guidelines for deciding when to invest in microcomputers. The authors argue that the technology and marketplace of micros today fits the conditions of the declining cost paradox observed by Eden and Ronen (1988). Under these conditions, a decision to defer purchasing equipment until the future to take advantage of hardware price decreases may lead to higher overall costs. The paper concludes with recommendations for the manager confronted with the decision of when to purchase microcomputer technology.

\section{INTRODUCTION}

Managers confront the decision of when to buy new technology when considering the purchase of personal computers. The user requesting personal computers wants to take advantage of improved computer performance. If the firm does not buy now it will lose the advantages it might gain from the new technology. The financial manager, however, may argue that the price of personal computers is droppping and that the organization should wait to purchase until some time in the future when the required investment will be less. The purpose of this paper is to offer an approach to the decision of when to buy personal computers in the face of declining hardware costs.

\section{THE DECLINING COST PARADOX}

In an earlier paper, Eden and Ronen (1988) developed a model of when to invest in technology in general under 
conditions of declining costs. In their research, the authors found a paradox: under certain conditions total costs might actually increase by waiting to purchase to take advantage of declining hardware costs! As stated by Eden and Ronen:

The greater the decline in the cost of a particular technology, the more urgent it may be to purchase the technology now.

The paradox only holds under certain conditions, and these conditions appear to characterize the current personal

computer industry.

Conditions of the Paradox

1.) The first condition required by the paradox is a decline in the expected cost to invest in the technology in the future. Certainly, for personal computers, there has been a steady reduction in the cost of individual components like the CPU, memcry, diskette and disk drives, and so on. (There have been temporary increases in component prices due to government trade policies and shortages, for example, the recent shortage and increase in the cost of 32 bit DRAMS. However, over the long run, costs have been declining as power has increased.)

2.) The second factor which contributes to the paradox is postponed or foregone benefits from the technology. The user must incur a cost by waiting for new technology. He or she has to postpone a planned application. The cost of being the fourth rather than the first airline reservations system to install personal computers in travel agents' 
offices is likely to be quite high. on the other hand, the cost of waiting for a 386 based machine to replace an 8088 PC for word processing is quite low.

3.) Eden and Ronen observe that there is tendency to spend about the same amount on a system despite the fact that components are dropping in price. Part of this tendency is forced on the consumer by vendors; it is very hard today to find an 8088 PC that comes with $64 \mathrm{~K}$ bytes of memory; vendors package machines with $256 \mathrm{~K}$ or more memory, typically $512 \mathrm{~K}$ or even $640 \mathrm{~K}$ bytes. While two diskette machines are available, most corporate buyers will opt for a hard disk unless the machine is to be a diskless workstation on a network.

The appeal of advanced features to users also encourages the tendency to buy more in the face of declining prices. In 1988 the Leonard N. Stern School of Business at NYU adopted a hard disk, color monitor system as its recommended computer for students in the Graduate Division. This configuration costs essentially the same as a two diskette model recommended the previous year. Both vendor offerings and the appeal of more powerful features to users encourage the purchase of systems whose total price does not decline as rapidly as the prices of their individual elements.

4.) Software advances have accompanied advances in hardware. New versions of software and entirely new types of programs are available for the user. In addition to the 
purchase price, users have a significant learning cost for software. The longer one waits to adopt the technology, the greater the learning costs are likely to be. The user who bought an early PC and learned to use Lotus version $1 \mathrm{~A}$ can make the transition to version 2 easily. The user who waited to buy a PC until version 2 of Lotus became available will have to learn a more complex piece of software.

5. The cost of PC software has not declined significantly. If anything, prices of software are rising as developers add more capabilities to their programs. The user who buys earlier can generally upgrade to subsequent versions of a package for a fee that is less than the purchase price of the new version.

The Tradeoffs

The Eden and Ronen model demonstrates under what conditions one should buy today rather than postpone a purchase. Intuitively, their model trades off the decline in the cost of technology against greater learning costs from postponing the purchase of a system. Foregone or postponed benefits are an important component of the model. The user who postpones purchase is likely to encounter steeper learning costs because advances in software will produce more complex and difficult to learn applications. The model also suggests that the decline in the costs of technology are partially offset by the tendency to purchase more powerful systems. As mentioned above, organizations today generally purchase a hard disk system as 
opposed to the original PC with diskette drives. (The hard disk system is also more complex to use than a two diskette PC.)

Figures 1 and 2 illustrate the tradeoff between the declining price of technology and the increasing costs of learning. In the figures the declining cost of hardware has been modeled by a curve of the form:

(1) betal + beta $2 * e^{- \text {alpha } t}$ where $t$ is time and alpha, betal and beta2 are parameters. Prices are expected to drop quickly and reach an asymptote where further reductions are unlikely using current technology.

The learning cost curve is modeled by:

(2) theta + gamma * $\log (t)$

where $t$ is time and theta and gamma are parameters. The total cost curve is the sum of the technology cost and learning cost curves. This illustration does not include considerations of postponed benefits; it simply shows the tradeoff between decreasing hardware costs and increasing learning costs over time.

Ignoring postponed benefits, in Figure 1 the minimum purchase cost comes around time 4 ; here the decision maker would have to consider postponing a decision to purchase until that time depending on the advantages accruing from purchasing earlier. In this example, costs for the technology drop more rapidly than the learning cost curve rises. In Figure 2, the shape of the curves suggests that 
based on technology cost declines and learning costs, one should purchase now.

\section{Benefits}

Based on costs alone, Figure 1 suggests that the decision maker may want to wait to invest in new technology. Whether or not one should wait to buy depends on the benefits expected from investing in the technology. What benefits would accrue to the organization from having the technology now rather than at time 4 ?

Figure 3 attempts to answer this question. Assume that two decisions are possible: purchase at time 1 or time 4 . Figure 3 shows two identical benefits curves for purchasing at these two times; it assumes that there are declining benefits from the investment and that if one waits until time 4 , the benefits curve will start at the same level as purchasing at time 1. At time 8 , the organization which purchased at time 1 will have obtained the benefits under the "purchase now" curve from times 1 to 8 . The organization which waited will have obtained only the benefits from time 4 to 8 under the "Purchase Later" curve.

The decision maker will have to balance the additional benefits of purchasing now against the cost savings from waiting until later to invest in the technology. 


\section{COMPONENTS OF THE PARADOX}

The paradox is based on five conditions described earlier. What is the evidence for the conditions leading to the Paradox for personal computers?

\section{Declining Hardware Costs}

The decline in PC hardware costs is well-known in the industry. The steady trend is to place more circuits on a chip which has helped to reduce the costs of computation. The decrease in cost per MIP is fairly steep and does not appear to approach an asymptote. While it is expected that silicon may reach a limit, faster chips are being fabricated out of galium arsenide. Laboratory researchers are working on heterojunction transistors which have attained switching speeds of 2 picoseconds or two orders of magnitude faster . than silicon chips. For the logic chips for PCs, costs have been decreasing as power has increased. In general the same trend has been observed for primary memory and disk storage. Benefits

As described above, the benefits from adopting the technology now rather than postponing the investment depend on the user and the organization; these benefits are unique to each purchase decision. Declining Costs, Steady Prices

The third condition of the paradox is the tendency for system costs to decline much more slowly than component costs because 1) vendors include more standard features in 
their products and 2) users are attracted to more advanced features.

Table 1 illustrates the costs of a typical pc-based workstation from 1983 through 1988. During this period the capabilities of the workstation have expanded as the total system cost has stayed nearly constant. The typical system doubled in memory and added a hard disk. Companies have gone from a two diskette system to a 20 or 40 megabyte hard disk XT or AT with enhanced color graphics as their standard machine.

Table 2 adds software to the analysis; software costs have fluctuated, but in general have not declined dramatically. New operating systems like os/2 are considerably more expensive than their predecessors, especially if the Presentation Manager is included.

Tables 2 and 3 illustrate that if one prices the systems that firms have typically adopted as their standard over time, system costs have not decreased as dramatically as the costs of individual components.

\section{Greater Complexity}

Greater complexity of systems and software lead to an increasingly steep learning cost curve. The demands on organizations for training and personal computer support are high. The greater the complexity of the software, the more difficult and costly it is likely to be to learn. The manager who postpones acquiring the technology until some 
time in the future will purchase hardware and software which will confront users with greater complexity. The IBM $P S / 2$ is a more complex machine than the original PC. The system features 3.5" instead of 5.25" diskettes and has a new bus called the microchannel. The system can be configured using software commands rather than hardware switches. When combined with new operating systems, the PS/2 should be capable of multiprocessing and multitasking. While the machine can be run as a first generation PC, its advanced features introduce new complexity for the user.

Tables 3 through 5 show changes in several popular software packages as they have passed through different versions. Between Lotus $1 \mathrm{~A}$ and 2.01, Lotus added a number of features and commands. Among the more notable addtions are matrix calculations and a regression procedure. Lotus 2 also provides string variables in addition to labels and values as data types.

Word Perfect has progressed from versions 3 through 5 over a relatively short period of time. A perusal of Table 4 shows that this application has grown from a relatively simple word processor to a package approaching the capabilities of desk top publishing software.

Table 5 contains changes in the database management system, DBASE, over time. Note that the manual for this popular database package has increased in size from 375 pages to over 1000. DBASE III+ has a screen painter and 
custom forms capability. DBASE III has 52 more commands than its predecessor while DBASE III+ has 104 more commands than version III. DBASE IV is in early release; advanced publicity indicates that it will be even more complex as it adds an SQL interface among other new features.

An analysis of these three products supports the contention that software is becoming more complex. These popular products do suggest a sharply increasing learning cost curve. The user who waits to invest in PC technology will be likely to encounter more complex software that is more difficult to learn than the early adopter of the technology. The later one purchases a system in general, the more difficult and costly to learn how to use it.

Many times decision makers do not take learning factors into account in analyzing the purchase of technology. While an emphasis on "user friendly" interfaces does facilitate familiarization with a system, learning to use the interface is only one part of learning to use a system or application. While software is becoming more friendly, designers are adding more features and options which increase the learning task.

\section{Software Prices}

Table 2 shows a modest decline in the price of software packages, though the decline is not dramatic. For some packages prices have remained the same or risen slightly with new releases. The expectation of declining software 
prices is certainly not a good reason to postpone investing in new PC technology.

\section{Summary}

For personal computers, the evidence suggests that the price of a typical PC system has remained steady because the vendor tends to add more features and the user tends to purchase systems with greater capabilities. Thus, while component prices are declining, system costs decrease less rapidly.

Workstations with more features and new releases of software are more complex, giving support to a rising learning cost curve. Over time, one can expect to pay more for training and lost time. One would also expect that upgrading from one version of a piece of software to the next would be easier than learning the most advanced version from scratch.

Software costs have not decreased as rapidly as hardware; in addition some software packages have experienced price increases.

Based on all of the evidence, it appears that conditions in the personal computer field meet the requirements for the declining price paradox to apply.

\section{IMPLICATIONS}

This paper has argued that just because hardware prices are expected to decrease in the future, one should not necessarily wait for these lower prices to purchase a 
personal computer system. Declining hardware costs must be traded off against:

1. Postponed benefits from waiting to adopt the technology.

2. The tendency for system costs to stay about the same.

3. Increasing system complexity leading to higher learning costs.

4. Minor changes in software costs.

What should a manager do when confronted with the question of when to invest in new PC technology? The first step is to estimate the benefits from acquiring PCs. Benefits include:

1. Greater productivity

2. Better communications

3. Reorganization of work

4. Faster response

5. Competitive advantage

6. Cost savings.

Estimate the benefits from adopting the technology now and the benefits of waiting, following the curves in Figure 3. Select an arbitrary point and assume that all of the benefits from both options are received at this point; in Figure 3 one might choose time 8 or 10.

Next, estimate from forecasts the extent to which system costs are likely to decline. Also predict the learning effort and costs for the intended users of the technology. Try to construct curves like Figures 1 and 2 . 
At the completion of the estimating process, the decision maker should have the following information:

An estimate through some future point in time of the benefits from purchasing now

An estimate of the benefits through some future point in time of waiting for a specified time period before purchasing, say time $t$

The current purchase price

The estimated purchase price at time $t$

The estimated learning costs now

The estimated learning costs at time $t$

Next subtract the costs associated with purchasing now from the benefits and do the same for purchasing later. If the later purchase is a year or more in the future, it may be necessary to apply a discounting factor to the future costs and to the benefits numbers. A comparison of the results should help the manager decide when to invest in new technology .

Consider the following numerical example:

Estimated benefits from purchasing now realized through month $12=200$

Estimated benefits through month 12 of waiting to purchase in month 6 (time $t)=175$

The current purchase price $=75$

The estimated purchase price in 6 months $=50$

The estimated learning costs now $=50$

The estimated learning costs in 6 months $=70$

Total current costs $=75+50=125$

Purchase now benefits - costs $=200-125=\underline{75}$ 


$$
\begin{aligned}
& \text { Total future costs }=50+70=120 \\
& \text { Benefits of waiting } 6 \text { months }=175-120=\underline{55} \\
& \text { (ignoring discounting) }
\end{aligned}
$$

In this example, the estimates suggest that the expected decrease in investment cost in six months does not offset higher learning costs and postponed benefits. In theory, one should apply a traditional discounted cash flow analysis to the numbers. However, given the tentative nature of the estimates and the short time times that will generally be involved in contemplating PC purchases, such added sophistication is probably not warranted.

The manager can conduct an analysis of the type suggested above to gain insight on the purchase decision. Intangible factors need to be combined with any numerical calculations. The purpose of such an analysis is to demonstrate that the idea of waiting for declining prices will not necessarily result in lower total system costs due to the declining cost paradox.

\section{CONCLUSIONS}

The purpose of this paper was to offer guidelines on the timing of an investment in PC technology when hardware component costs are declining. Because of the declining cost paradox, it does not follow from decreases in hardware component costs that one should necessarily wait to invest.

The paper identifies a number of factors to be considered by the decision maker in choosing when to invest in the technology. One must balance the declining costs of 
hardware components against greater learning costs from waiting to invest and against lost opportunity costs. Also, the decision maker should be aware that the cost of a total system tends not to decrease as rapidly as component costs and that software costs may not decline at all. Based on the evidence presented in this paper, for personal computers it appears that often the decision will be to invest in new technology sooner rather than later. 
REFERENCES

(1) Bendre, Eric. "Ashton - Tate dBase 111 + Scheduled for Comdex Rollout," Computerworld, Nov. 18, 1985, p. 6 .

(2) Birmele, Ricardo. "Software Review: WordPerfect," Byte, Dec. 1984, pp. 277-288.

(3) Bond, George. "A Database Catalog," Byte, Oct. 1984, pp: 227-288.

(4) Byers, Robert A. dBase III for Every Business, Culver City: Ashton - Tate Publishing Group, 1985.

(5) Currie, Steven. Understanding and Using dBase III on the PC, New York: Holt, Rinehart, and Winston, 1986.

(6) Eden, Yoran and Boaz Ronen. "The Declining Cost Paradox of New Technologies", Working Paper, Faculty of Management,

Tel Aviv University, Dec. 1988.

(7) Emerson, Sandra L. and Marcy Darnovsky. Database for the IBM PC, Reading: Addison - Wesley Publishing Company, 1984 .

(8) Hession, William. Performance Guide to Word Processing Software, New York: McGraw-Hill, 1985.

(9) Jacobson, Bill. "DataEase vs. Condor and dBase 11," Byte, oct. 1984, pp: 289-302.

(10) Jones, Mitt. "WordPefect 4.2 Improves Indexing, Adds Document Preview, Hidden Notes," PC Magazine, Jan 27, 1987, p. 48 .

(11) Kruglinski, David. "Update on Six Database Managers," Byte, Fall 1984 (special issue), pp: 187-196.

(12) LeBlond, Geoffrey T. et al. Using 1-2-3, 1st ed., Indianapolis: Que Corp., 1983.

(13) LeBlond, Geoffrey T. et al. Using 1-2-3, 2nd ed. Indianapolis: Que Corp., 1985.

(14) Liskin, Miriam. Advanced dBase III: Programming and Techniques, Berkeley: McGraw-Hill, 1986.

(15) McMahon Marilyn et al. Report writing in dBase II, Arlington, Mass.: SoftwarBanc; Englewood Cliffs, N.J.: Prentice-Hall, 1984.

(16) Microworld: Software/Hardware Selection Guide, Pennsauken, N.J.: Auerbach Publishers. 
(17) Nelson, Robin. "dBase III: A Data Base fro Real People," Personal Computing, Oct. 1984, pp: 259-268.

(18) Poor, Alfred. "Database Power Puts on An Easy Interface." PC Magazine, Jan. 27, 1987, pp: 109-117.

(19) Porter, Kent. "dBase III Plus for Nonprogrammers." Business Software, August 1986, pp: 66-77.

(20) Simpson, Alan. Understanding dBase II. Berkeley: Sybex, Inc., 1984 .

(21) Simpson, Alan. Understanding dBase III Plus, Berkeley: Sybex, Inc., 1986.

(22) Taylor, Jared. "Lotus Makes New Waves," PC Magazine, 26 Nov. 1985, pp: 35-36.

(23) Urschel, William. "Data Base Management Software." Personal Computing, March 1985, pp: 241-249.

(24) Wiswell, Phil. "Word Processing: Eighteen popular word processors get a thorough workout..." PC Magazine, Aug. 20, 1985, pp: 110-134.

(25) Zilbergeld, Bernie. "Wordperfect 4.1: The Best Improved." Infoworld, Nov. 4, 1985, pp: 41-43. 
Cost Reduction Vs the Learning Curve

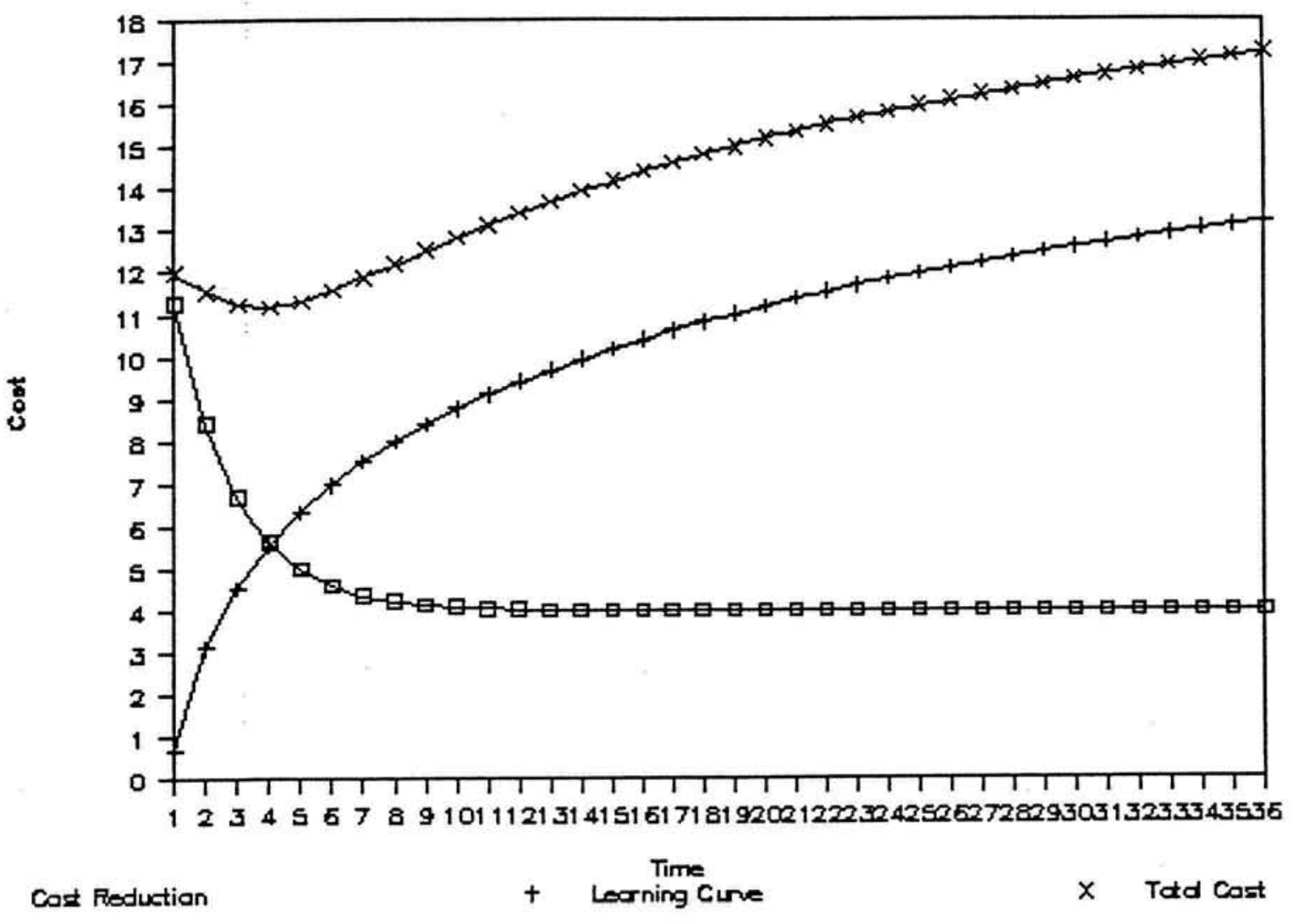

Figure 1 
Cost Reduction Vs the Learning Curve
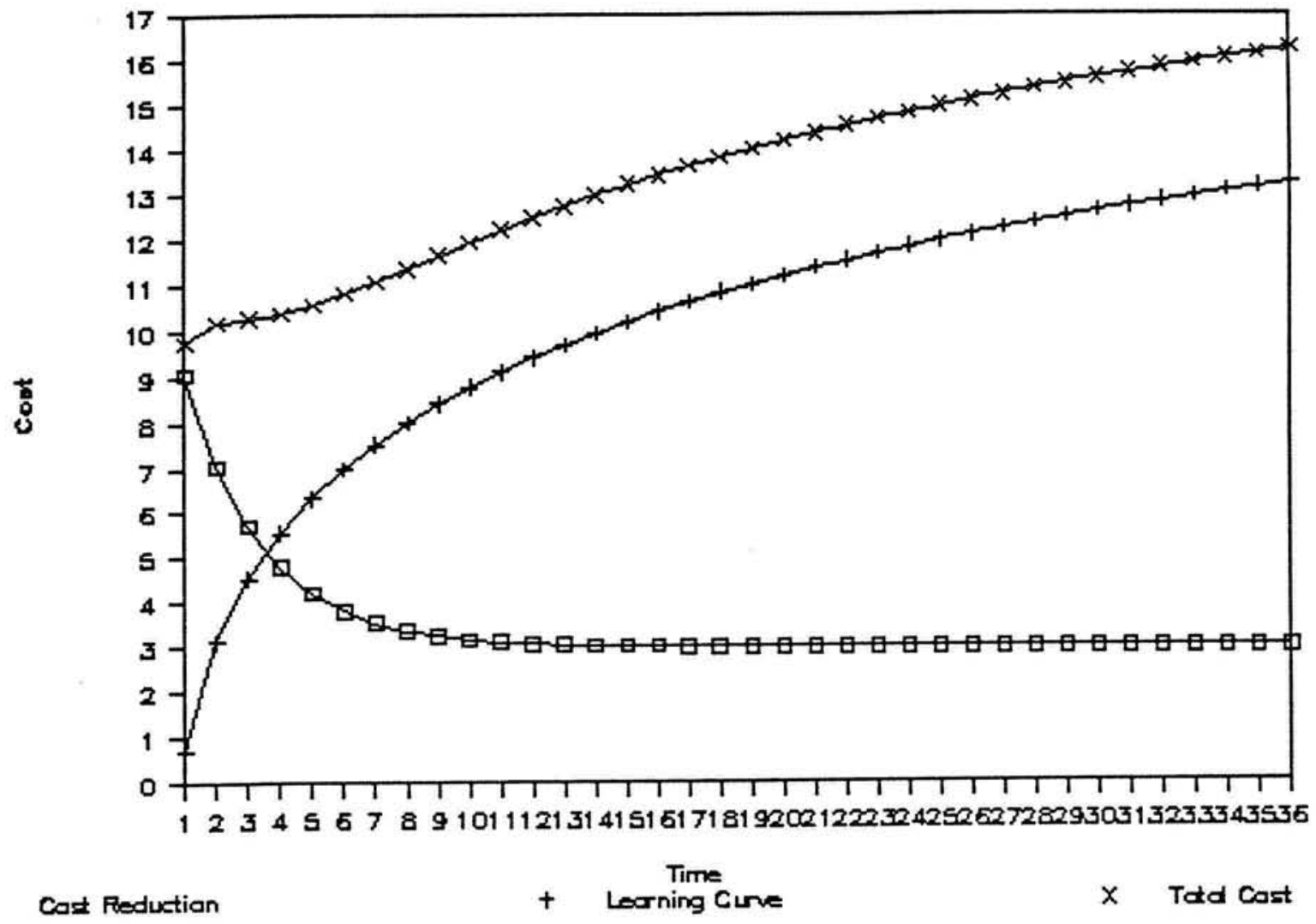

Figure 2 


\section{Benefits}

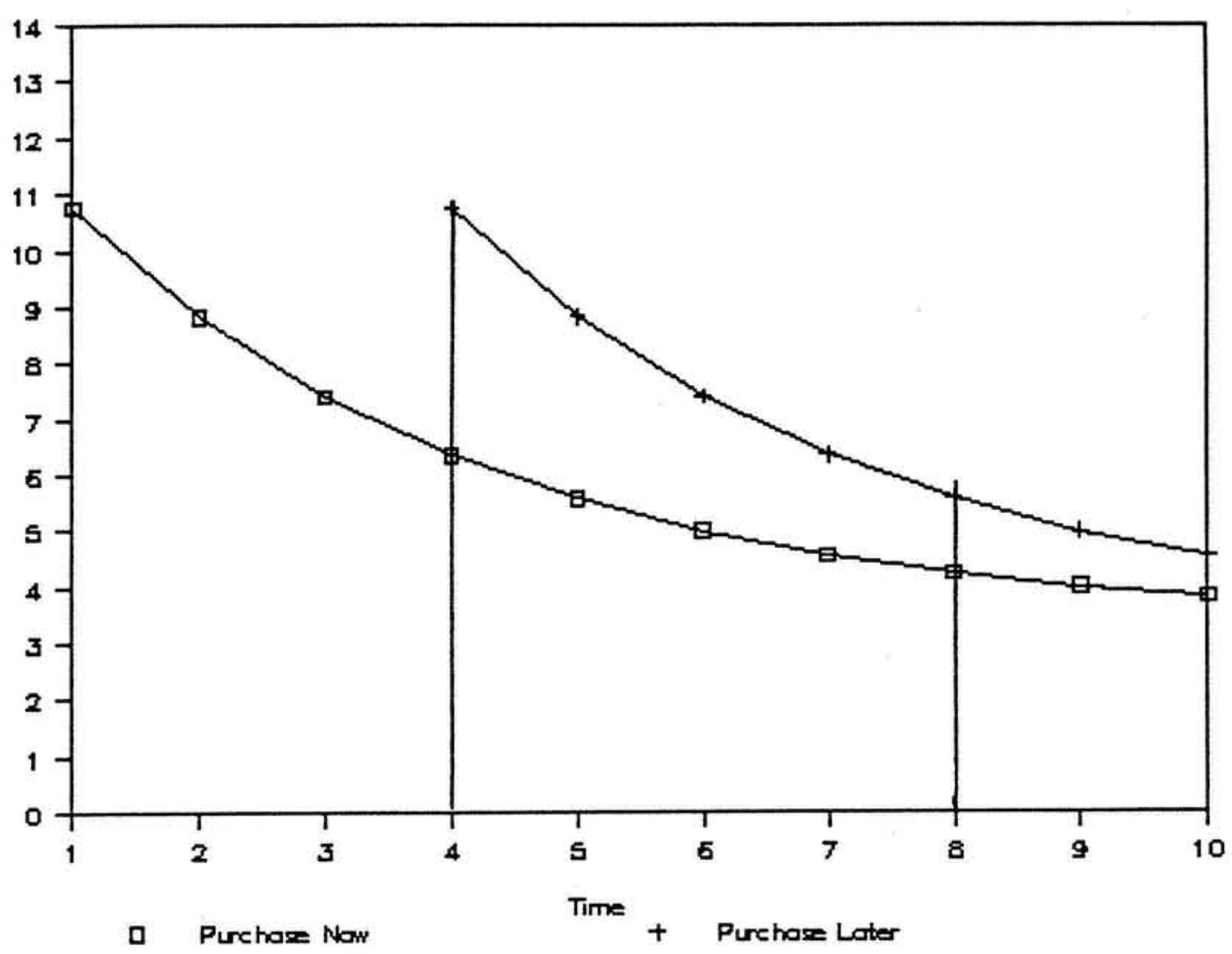

Figure 3 
TABLE I

TRENDS IN PC COSTS

(When a category has more than one model the latest model and price are used in calculation of total prices).

$\begin{array}{lllllll}\text { PRODUCT (HARDWARE) } & 1983 & 1984 & 1985 & 1986 & 1987 & 1988\end{array}$

IBM PC (256K 2 DR.

MONO DISP) $\quad 3430$

SAME ABOVE + 128K 3000

SAME ABOVE + 256K

1OMb HARD

$2800 \quad 1826$

IBM XT 10MB HARD + $256 \mathrm{k}$

$\begin{array}{lll}3450 & 2713 & 1483\end{array}$

IBM AT 20MB HARD + $512+1.2 \mathrm{Mb}$ FLOPPY MONO DISP

4522 3331

DELI 286/220, 4MEG HARD, VGA COLOR

579

389

375

EPSON FX80

EPSON FX85

EPSON FX86e

EPSON LQ-2550

IBM MONO DISP

IBM COLOR

579

IBM ENHANCED COLOR

335

335

248

589

234

603

3299

IBM PRTNT ADPT

234

234

234

219

218

IBM CGA

IBM EGA

SMARIMODEM 300

1200

$1200 \mathrm{~B}$

2400

234

533

211

197

457

376

449

AST 6PAKPLUS 64K

277

262

228

336

384

939

ABOVE BOARD 2 INTEL

472

381

339

223

538

665

400

129

385

338

169

479 
TRENDS IN SOFTWARE COSTS

TABLE 2

ACIUAL SEITING PRICES

(When a category has more than one model the latest model and price are used in calculation of total prices).

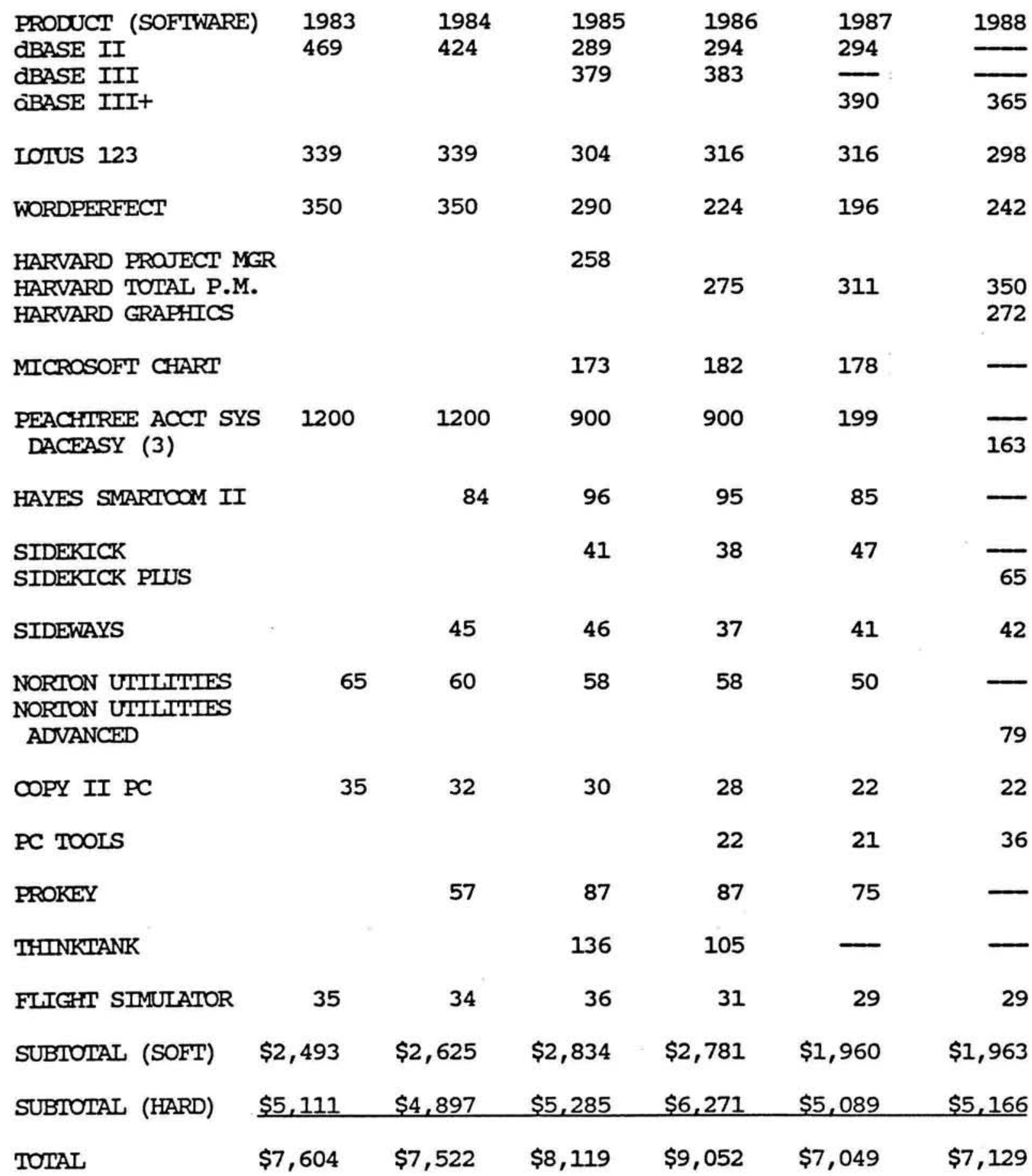




\section{LOTUS FEATURES}

TABLE 3

LOTUS

FEATURE
LOTUS VERSIONS

$1 \mathrm{~A}$

2.01

$\$ 495$

256K RAM

4 Mbyte

NO

5

6

362

350

NO

YES

NO

YES

2048

8192

YES

LEAVING LOTUS

TRANSFER FILES BETWEEN

YES

YES

dBASE II AND LOTUS

NO

YES

AND LOTUS

PASSWORD PROTECTION

NO

YES

PAGE BREAKS

NO

YES

SAVE BLANK CELLS

YES

NO

OPTION TO ADD OWN FILE

NO

YES

EXTENSION

MAIN MENU COMMANDS

9

10

SYSTEM COMMAND
No 
LOTUS

FEATURE
LOTUS VERSIONS

$1 \mathrm{~A}$

2.01

SUBOPTIONS IN/WORKSHEET

68

115

IN/RANGE

31

42

IN/FILE

25

27

IN/PRINT

32

32

STATISTICAL

7

7

DATA BASE STATISTICAL

3

4

SPECIAL

4

11

MACROS :

KEYWORK REPRESENTATIONS

22

25

COMMANDS

8

48

PAGES IN MANUAL

13

57

IN/GRAPH

99

108

IN/DATA

26

48

GRAPH TYPES

5

6

HIDDEN CELLS AND COLUMNS

NO

YES

RANGE TABLES

NO

YES

TRANSPOSE ROWS/COLUMS

NO

YES

CONVERTS FORMULAS TO VALUES

NO

YES

HIDDEN FORMATS

NO

YES

DATE FORMATS

3

5

TIME FORMATS

NO

YES

CLOCK/CALENDAR IN LOWER

LEFT CORNER

NO

YES

NO

YES 
LOTUS

FEATURE

REGRESION

PARSING

INTERNATIONAL PUNCTUATION

INTERNATIONAL DATE/TIME

INTERNATIONAL CURRENCY

ESIGN FUNCTIONS:

MATHEMATICAL

FINANCIAL

LOGICAL

STRING

DATE AND TIME
LOTUS VERSIONS

$1 \mathrm{~A}$

2.01

NO

YES

NO

YES

NO

YES

NO

YES

NO

YES

17

17

5

11

1

3

0

17

5

11 
LOTUS: LEARNING 1A FROM SCRATCH

NUMBER OF DISKS

$\begin{array}{ll}\text { PAGES IN MANUAL } & 362\end{array}$

MAIN MANU COMMANDS 9

FUNCTION KEYS USED 11

(combo of keystrokes)

WORKSHEET OPTIONS 68

RANGE OPTIONS 31

FILE OPTIONS $\quad 25$

GRAPH OPTIONS 99

$\begin{array}{ll}\text { DATA OPTIONS } & 26\end{array}$

MACRO COMMANDS 8

PAGES IN MANUAL ON MACROS 13

@SIGN: $\quad 17$

MATHEMATICAL

FINACIAL $\quad 5$

LOGICAL

STRING 0

DATE AND TIME $\quad 5$

$\begin{array}{ll}\text { STATISTICAL } & 7\end{array}$

DATA BASE STATISTICAL 3

SPECIAL $\quad 4$

INTERNATIONAL OPTIONS IN 0

SPREADSHEET

INTERNATIONAL OPTIONS IN GRAPH 0

SCALING

DATE FORMATS 3 
$-27-$

LOTUS: LEARNING 1A FROM SCRATCH

TIME FORMATS 
LOTUS: ADITIONAL, FROM IA TO 2.0

NUMBER OF DISKS

PAGES IN MANUAL 12

MAIN MENU COMMANDS 1

FUNCTION KEYS USED 1

(combo of keystrokes)

47

RANGE OPTIONS 11

FILE OPTIONS 2

$\begin{array}{ll}\text { PRINT OPTIONS } & 0\end{array}$

GRAPH OPTIONS 9

DATA OPTIONS 22

MACRO COMMANDS 40

PAGES IN MANUAL ON MACROS 44

QSIGN : 0

MATHEMATICAL .

FINANCIAL 6

LOGICAL 2

$\begin{array}{ll}\text { STRING } & 17\end{array}$

DATE AND TIME 6

$\begin{array}{ll}\text { STATISTICAL } & 0\end{array}$

DATA BASE STATISTICAL 1

$\begin{array}{ll}\text { SPECIAL } & 7\end{array}$

INTERNATIONAL OPTIONS IN 28

SPREADSHEET

INTERNAITONAL OPITONS IN GRAPH 4 SCALING 
LOTUS: ADITIONAL, FROM IA TO 2.0

DATE FORMATS 2

TIME FORMATS 4

GRAPH TYPES 1 
WORDPERFECT FEATURE

TABLE 4

WORDPERFECT

VERSIONS

FEATURE

$3.0 \quad 4.0$

4.1

4.2

5.0

$\longrightarrow$

FOOTNOTE SEARCH

HEADERS/FOOTERS SEARCH

SEARCH FOR COMBINATION

OF WORDS

SPLIT-SCREEN

HORIZONTAL

- DRAWS VERTICAL AND

HORIZONTAL LINES

CAN DO CENTER AND

FLUSH RIGHT IN BLOCK

SORTING

DOCUMENT SUMMARY

OPTION

CREATES TABLE OF

REFERENCES

AUTOMATIC REFERENCE TO

PAGE NUMBER BY NAME

COLOR GRAPHICS

CAPABILITIES

DESKTOP PUBLISHING

FLEXIBLE STYLE SHEETS

STYLES CREATION

MASTER DOCUMENT

KERNING OPTION
NO

NO

NO

NO

NO

NO

NO

NO

No

NO

NO

NO

NO

NO

NO

NO

No

NO

NO

NO

No

No

NO

No

NO

NO

NO

NO

NO

NO
NO

YES

YES

NO

NO

YES

NO

NO

YES

NO

NO

YES

NO

NO

YES

NO

NO

YES

NO

NO

YES 
VERSIONS

FEATURE

VARIABLES OF

SUBROUTINE MACROS

CUSTOM MENUS CREATION

MNEMONICS ABREVIATED

SUBMENUS

CURSOR MOVEMENT:

TOP/BOTTOM SCREEN

END/BEGIN LINE

ENDS OF DOCUMENT

DELETION :

FOOTNOTES BY WORD

BY SENTENCE

BY PARAGRAPH

BY LINE

BY BLOCK

UNDEI_ETE

3 LEVEL UNDELETE

PROPORTIONAL SPACING

REPAGINATION

INDEXING FUNCTION

KEYBOARD INPUT WHILE

PRINTING

IMPORT/EXPORT FILE

CONVERSION
3.0

4.0

4.1

4.2

5.0

NO

NO

NO

NO

YES

No

NO

No

NO

YES

NO

NO

No

NO

YES

\begin{tabular}{|c|c|c|c|c|}
\hline YES & YES & YES & YES & YES \\
\hline No & YES & YES & YES & YES \\
\hline YES & YES & YES & YES & YES \\
\hline
\end{tabular}

YES

YES YES

YES

YES

No

YES YES

YES YES

NO

YES YES

YES YES

YES

YES YES

YES YES

YES

YES YES

YES YES

NO

YES YES

YES YES

NO

NO YES

YES YES

No

YES YES

YES YES

NO

YES YES

YES YES

NO

YES YES

YES YES

NO

YES

YES

YES YES

No

YES

YES

YES YES 
VERSIONS

FEATURE

CONCORDANCE FILES FOR

AUTOMATIC INDEXING

OPTION TO EMBED/DISPLAY

COMMENTS

PREVIEW DISPLAY OF

PRINT FORMAT OF DOC.

WILD CARD SEARCH

DOCUMENT NAME

DISPLAY

- GRAPHIC FILE

NAME DISPLAY

PRICE

NO. OF DISKS

(5 1/4)

MICROPROCESSOR

VIRTUAL MEMORY

FUNCTION KEY

DRIVEN

SUBMENUS

(CHOOSE BY LETTERS)

MINIMUM MEMORY

SCREEN-ORIENTED

ON LINE TUTORIAL

WORD DICTIONARY

ENCRYPTION/

PASSWORD

MACROS

\begin{abstract}
3.0
\end{abstract}
4.0

$4 \cdot 1$

4.2

5.0

NO

No

NO

YES

YES

NO

No

No

YES

YES

No

No

No

YES

YES

NO

YES

YES

YES

YES

NO

NO

NO

YES

YES

NO

No

No

NO

YES

$\$ 495 \quad \$ 495 \quad \$ 495 \quad \$ 495 \quad \$ 495$

2

4

4

4

12

16 BIT 16

16

16

16

YES

YES

YES

YES

YES

YES

YES

YES

YES

YES

YES

YES

YES

YES

YES

$128 \mathrm{~K} \quad 192 \mathrm{~K} \quad 256 \mathrm{~K} \quad 256 \mathrm{~K} \quad 384 \mathrm{~K}$

YES YES YES YES YES

NO

No

No

YES

YES

$$
30 \text {, }
$$

YES YES

100,000

120,000

120,000

YES

YES

$120,000+$

YES

YES

YES

YES

YES 
VERSIONS

FEATURE

CORRECTS

MISSPELLED WORDS

IINDICATES CORRECT

SPELLING IN LOWER HALF

OF SCREEN WORD FOR

CORRECT SPELLING

HAVE TO LOOK UP WORD

FOR CORRECT SPELLING

ALLOWED TO EXIT

DICTIONARY AT CHOICE

THESAURUS

CURSOR MOVEMENT:

BY WORD

BY SENTENCE

BY PARAGRAPH
3.0

4.0

4.1

4.2

5.0

NO

NO

NO

NO

No

NO

YES

YES

YES

YES

YES

NO

No

NO

No

NO

No

NO

NO

YES

NO

NO

YES

YES

YES

YES

YES

YES

YES

YES

NO

YES

YES

YES

YES

No

YES

YES

YES

YES 
TABLE 5

DBASE FEATURES

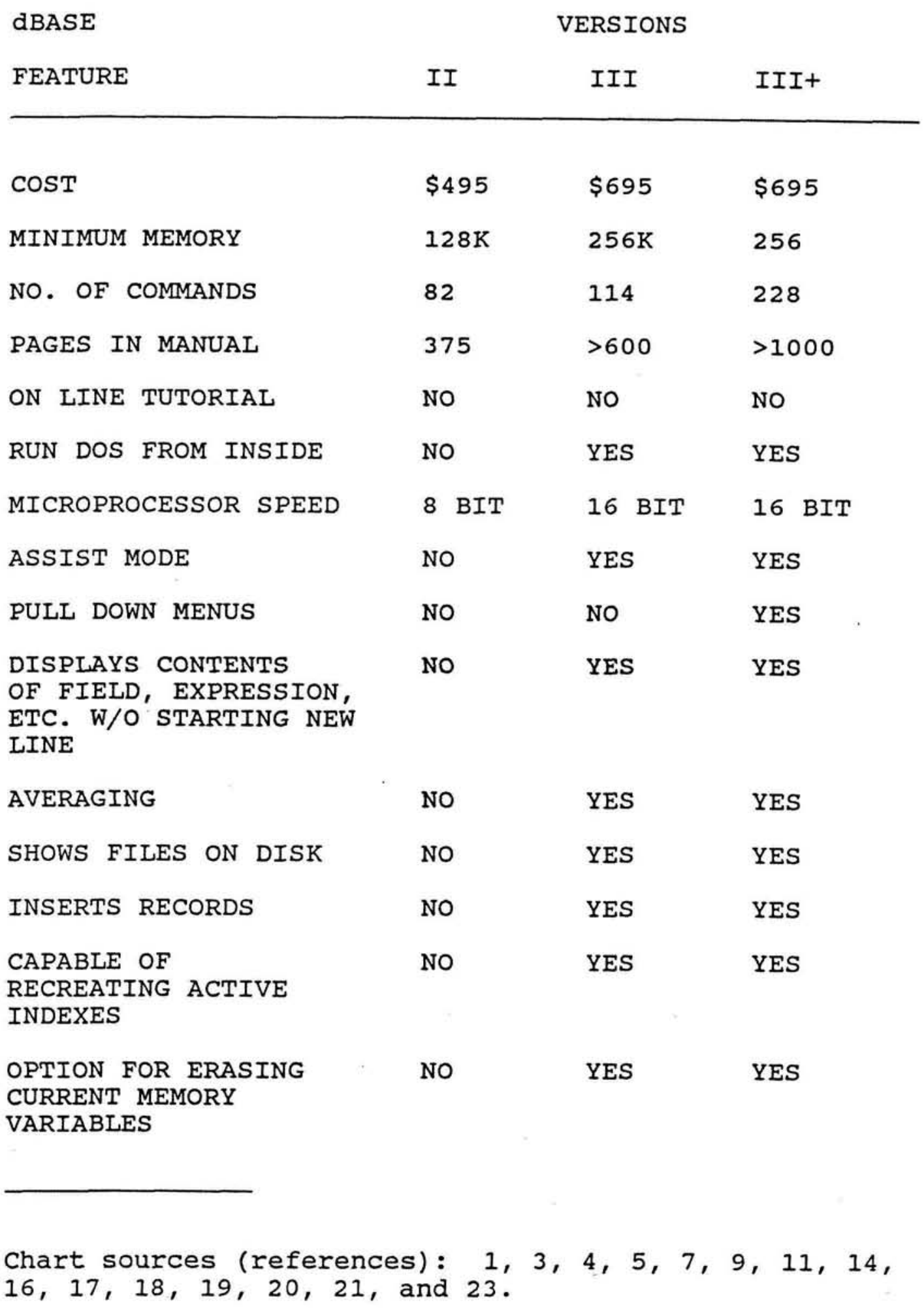


dBASE

FEATURE

ALLOWS USER TO SELF

PROGRAM FUNCTION KEYS

CHARACTERS PER FIELD

MAX. CHARACTERS PER

RECORD

MEMO FIELDS

DATE FIELDS

MAXIMUM FIELDS PER

RECORD

RECORDS PER FILE

MULTIPLE RECORDS

SHOWN FOR EDITING

CAN UNDO CHANGES

"MODIFY STRUCTURE"

ERASES ALL RECORDS

INTERNATIONAL DATE

FORMATS

SET JUSTIFICATION

HEADING AND FOOTINGS

SCREEN PAINTER FOR

CUSTOM FORMS

FILES THAT CAN BE

OPEN SIMULTANEOUSLY

STORABLE MEMORY

VARIABLES

MATHEMATICAL

OPERATIONS

EXPONENTIAL AND LOG
NO

II

III+

254

1,000

NO

YES

YES

NO

YES

YES

32

128

128

65,535 UNLIM. UNLIM.

NO NO NO

NO YES YES

YES

NO

NO

No

NO

YES

NO

NO

YES

No

YES

YES

NO

No

YES

2

10

10

64

256

256

4

NO

YES
6

YES 


\begin{tabular}{|c|c|c|c|}
\hline dBASE & & VERSIONS & \\
\hline FEATURE & II & III & III+ \\
\hline DATA TYPES & 3 & 5 & 5 \\
\hline AUTOMATIC INDEX UPDATE & LIMIT. & FULL & FULL \\
\hline USES IBM FUNTION KEYS & No & YES & YES \\
\hline CLEARS ERROR MESSAGES & No & YES & YES \\
\hline $\begin{array}{l}\text { HANDLING OF DISK } \\
\text { OVERFLOW }\end{array}$ & CRASH & MESSAGE & MESSAGE \\
\hline PASSWORD PROTECTION & No & No & NO \\
\hline WORD PROCESSING & NO & YES & YES \\
\hline $\begin{array}{l}\text { COMBINE FOR AND WHILE } \\
\text { SAME CONDITION }\end{array}$ & NO & No & YES \\
\hline $\begin{array}{l}\text { DISPLAYS ACSII VALUE } \\
\text { OF CHARACTER }\end{array}$ & No & YES & YES \\
\hline $\begin{array}{l}\text { ARE REPORT FILES ASCII } \\
\text { FILES }\end{array}$ & YES & No & No \\
\hline NETWORKING CAPABILITIES & No & No & YES \\
\hline SECURITY LEVELS & NONE & NONE & 8 \\
\hline DATA ENCRYPTION & NO & NO & YES \\
\hline WILDCARD SEARCHES & NO & No & YES \\
\hline $\begin{array}{l}\text { AUTOMATIC HISTORY } \\
\text { STORING OF COMMANDS } \\
\text { FOR RECALL }\end{array}$ & No & No & YES \\
\hline VIEW FILES & No & NO & YES \\
\hline $\begin{array}{l}\text { SAVES AND RECALLS } \\
\text { QUERIES }\end{array}$ & NO & NO & YES \\
\hline
\end{tabular}


ABASE II: LEARNING FROM SCRATCH

NUMBER OF COMMANDS $\quad 75$

EDITING COMMNADS 9

APPEND FUNCTIONS 2

CLEAR COMMANDS 0

COPY COMMANDS 1

CREATE COMMANDS 1

DISPLAY COMMANDS 3

DO COMMANDS . 2

MODIFY COMMANDS 3

PROCESSING PROGRAM COMMANDS 14

SORTING COMMANDS 2

COMMANDS FOR LOCATING RECORDS 2

STRING FUNCTION COMMANDS 3

STRING OPERATORS 4

MATHEMATICAL FUNCTIONS 3

MEMORY VARIABLE COMMANDS 9

LIMIT ON MEMORY VARIABLES STORED 64

CHARACTER CONVERSION FUNCTIONS 2

IF COMMANDS 1

DATE AND TIME FUNCTIONS 1

DEBUGGING TECHNIQUES 6

COMMANDS FOR INTERFACING WITH 2

OTHER SOFTWARE 
ADDITIONAL, FROM ABASE II TO III

NUMBER OF COMMANDS

EDITING COMMANDS

APPEND FUNCTIONS

CLEAR COMMANDS

COPY COMMANDS

CREATE COMMANDS

DISPLAY COMMANDS

DO COMMANDS

MODIFY COMMANDS

PROCESSING PROGRAM COMMANDS

SORTING COMMANDS

COMMANDS FOR LOCATING RECORDS

STRING FUNCTION COMMANDS

STRING OPERATORS

MATHEMATICAL FUNCTIONS

MEMORY VARIABLE COMMANDS

STORABLE MEMORY VARIABLES

CHARACTER CONVERSION FUNCTIONS

IF COMMANDS

DATE AND TIME FUNCTIONS

DEBUUGGING TECHNIQUES

COMMANDS FOR INTERFACING WITH OTHER SOFTWARE
52

3

1

4

2

2

1

1

1

19

1

2

6

0

2

4

192

7

0

9

2

0 
dBASE III: LEARNING FROM SCRATCH

$\begin{array}{ll}\text { NUMBER OF COMMANDS } & 127\end{array}$

EDITING COMMANDS 12

APPEND FUNCTIONS 3

CLEAR COMMANDS 4

COPY COMMANDS 3

CREATE COMMANDS 3

DISPLAY COMMANDS 4

DO COMMANDS 3

MODIFY COMMANDS 4

PROCESSING PROGRAM COMMANDS 33

SORTING COMMANDS 3

COMMANDS FOR LOCATING RECORDS 4

STRING FUNCTION COMMANDS 9

STRING OPERATORS 4

MATHEMATICAL FUNCTIONS 5

MEMORY VARIABLE COMMANDS 13

STORABLE MEMORY VARIABLES 256

CHARACTER CONVERSION FUNCTIONS 9

IF COMMANDS 1

DATE AND TIME FUNCTIONS : 10

DEBUUGGING TECHNIQUES 8

COMMANDS FOR INTERFACING WITH 2 OTHER SOFTWARE 


\begin{tabular}{|c|c|}
\hline NUMBER OF COMMANDS & 104 \\
\hline EDITING COMMANDS & 0 \\
\hline APPEND FUNCTIONS & 0 \\
\hline CLEAR COMMANDS & 2 \\
\hline COPY COMMANDS & 0 \\
\hline CREATE COMMANDS & 3 \\
\hline DISPLAY COMMANDS & 1 \\
\hline DO COMMANDS & 0 \\
\hline MODIFY COMMANDS & 2 \\
\hline PROCESSING PROGRAM COMMANDS & 10 \\
\hline SORTING COMMANDS & 0 \\
\hline COMMANDS FOR LOCATING RECORDS & 0 \\
\hline STRING FUNCTION COMMANDS & 6 \\
\hline STRING OPERATORS & 2 \\
\hline MATHEMATICAL FUNCTIONS & 4 \\
\hline MEMORY VARIABLE COMMANDS & 3 \\
\hline CHARACTER CONVERSION FUNCTIONSO & \\
\hline IF COMMANDS & 1 \\
\hline DATE AND TIME FUNCTIONS & 2 \\
\hline DEBUUGGING TECHNIQUES & 6 \\
\hline $\begin{array}{l}\text { COMMANDS FOR INTERFACING WITH } \\
\text { OTHER SOFTWARE }\end{array}$ & 2 \\
\hline QUERY FORM OPTIONS & 5 \\
\hline HISTORY COMMANDS & 3 \\
\hline
\end{tabular}


ADITIONAL, FROM ABASE III TO III+

?IS... COMMANDS

FUNCTION KEY COMMANDS
4

4 
NUMBER OF COMMANDS 231

EDITING COMMANDS 12

APPEND FUNCTIONS 3

CLEAR COMMANDS $\quad 6$

COPY COMMANDS 3

CREATE COMMANDS 6

DISPLAY COMMANDS 5

DO COMMANDS 3

MODIFY COMMANDS 6

PROCESSING PROGRAM COMMANDS 43

SORTING COMMANDS 3

COMMANDS FOR LOCATING RECORDS 4

STRING FUNCTION COMMANDS 15

STRING OPERATORS 5

MATHEMATICAL FUNCTIONS 9

MEMORY VARIABLE COMMANDS 16

CHARACTER CONVERSION FUNCTIONS 9

IF COMMANDS 2

DATE AND TIME FUNCTIONS 12

DEBUUGGING TECHNIQUES 14

COMMANDS FOR INTERFACING WITH 4

OTHER SOFTWARE

QUERY FORM OPTIONS 5

HISTORY COMMANDS 3 


$$
-43-
$$

dBASE III+: LEARNING FROM SCRATCH

?IS... COMMANDS

4

FUNCTION KEY COMMANDS 